\title{
Rethinking Digital Literacy Practices and Educational Agendas in Times of Covid-19 Uncertainty
}

\section{Repensando práticas de letramento digital e agendas educacionais em tempos de incerteza da Covid-19}

\author{
William Mineo Tagata* \\ *Universidade Federal de Uberlândia (UFU), Uberlândia, Minas Gerais / Brasil \\ wtagata@gmail.com \\ http://orcid.org/0000-0001-6785-0841 \\ Fernanda Costa Ribas** \\ **Universidade Federal de Uberlândia (UFU), Uberlândia, Minas Gerais / Brasil \\ ribasileel@gmail.com
}

http://orcid.org/0000-0002-9116-2501

\begin{abstract}
In this article, we problematize literacy issues in the current context of instability and uncertainties generated by the Covid-19 pandemic, from its social, political and educational impacts. Our discussion will focus on fictional vignettes that we composed based on real stories circulating in the media and social networks, and marked (but not restricted to) by the intense use of digital technologies. Our aim is to formulate questions about the relationship among society, literacy, technology and education, which have been of primary concern to us as teachers and researchers of languages and literacy. We do not intend to offer definitive answers or solutions, but only to suggest research paths for studies in literacy and Applied Linguistics, in light of concepts such as multiplicity, emotions, rhizome and nomadic thought.
\end{abstract}

KEYWORDS: digital literacy; education; neoliberalism; nomadic thought; desire.

RESUMO: Neste artigo, problematizamos questões de letramento em meio ao atual contexto de instabilidade e incertezas gerados pela pandemia de Covid-19, a partir de seus impactos sociais, políticos e educacionais. Nossa discussão será centrada em vinhetas fictícias, baseadas em histórias reais, circulando na mídia e nas redes sociais, marcadas pelo (mas não restritas ao) uso intenso de tecnologias digitais. Nosso objetivo é formular perguntas acerca da relação entre sociedade, letramento, tecnologia e educação, as quais têm nos incomodado enquanto 
professores e pesquisadores de línguas e letramento. Não pretendemos oferecer respostas ou soluções definitivas, mas apenas sugerir caminhos de investigação para os estudos em letramento e Linguística Aplicada, à luz de conceitos como multiplicidade, emoções, rizoma e ecologia de saberes.

PALAVRAS-CHAVE: letramento digital; educação; neoliberalismo; pensamento nômade; desejo.

Desire is present wherever something flows and runs, carrying along with it interested subjects -but also drunken or slumbering subjects- toward lethal destinations.

(Deleuze and Guattari, A Thousand Plateaus)

The death of a social machine has never been heralded by a disharmony or a dysfunction; on the contrary, social machines make a habit of feeding on the contradictions they give rise to, on the crises they provoke, on the anxieties they engender, and on the infernal operations they regenerate. Capitalism has learned this, and has ceased doubting itself, while even socialists have abandoned belief in the possibility of capitalism's natural death by attrition. No one has ever died from contradictions.

(Deleuze and Guattari, AntiOedipus)

\section{Introduction}

We are all going through crises of some sort, everywhere, all the time. From personal, existential, midlife crises to those affecting people on a vast scale, with far-reaching and long-standing effects that could span years or even decades. The latter seems to be the case of the present Covid-19 pandemic. For professionals working in the field of education, the pandemic has posed a number of challenging questions, perhaps the most pressing of which is how to harness digital technologies to salvage the academic year. We can only hope that remote learning mediated by digital technologies can help to minimise the problems caused by the worldwide disruption of formal schooling programmes. However, these technologies can hardly be considered a panacea to all our educational problems, some of which aggravated by the pandemic. Hopefully this health crisis could also yield social and educational benefits from a reassessment of aims and goals that could gradually change the very nature of education and literacy as we 
know it. One of these benefits could be imagining ways of conceiving of the relationships between society, literacy, and schooling anew, so as to be able to pose relevant problems for literacy and learning in while and post-pandemic times and come to terms with the uncertainties that have assailed us all.

Biesta's (2015a) contention that education should be about the emergence of unique, singular human beings, in situations where their agency can be fully developed and exercised, suggests that we conceive of schools as institutional settings where outcomes should not be fully known or determined in advance. According to Biesta, this is most likely to occur in societies in which democracy is already consolidated. Yet this is not the case in Brazil, a country still plagued by great social and economic inequities. One example of such inequities is the digital divide made evident by the pandemic crisis, during which public school students and teachers who cannot afford high speed Internet have been struggling with remote education.

This paper is not about the use of digital technologies per se, but rather about the meaning making processes that students, teachers and society at large are engaged in during the pandemic. Naturally, digital technologies are at the core of some of these processes, and as teachers we are particularly interested in formal educational settings. However, our reflections in this paper are more directly related to what the deployment of these technologies tells us about the changing nature of literacy and learning nowadays, and the political, economic and educational hardships that have been worsened by the Covid-19 pandemic in Brazil. Some of the questions that have guided our reflections are: how can literacy be conceived of so as to take account of the increasingly complex meaning making processes people have been resorting to during the pandemic? Can literacy still be approached as a set of discrete skills (digital, literary, critical, informational, visual, among others) or what are the shortcomings of this approach? In what ways have digital technologies been used to promote remote learning, as well as enhance interpersonal communication in times of physical distancing? If, as Biesta (2015a, p. 148) suggests, "the responsibility of the educator is a responsibility for what is to come, without knowledge of what is to come", how can we as educators not only cope with our present uncertainties but also to educate for the new, the unpredictable, in such ways as to promote the emergence of democratic subjectivities? 
Any answers to the questions outlined above are necessarily tentative, relatable only to specific social contexts ${ }^{1}$ and the multiple forces at play therein. Searching for answers thus entails an awareness of the elusive character of language and literacy practices; indeed, there always seems to be something that escapes our attention, given our inability to take account of the multiplicity of meaning making processes in any communicative situation, characterized by a unique interplay of contextual factors relating to the participants, the environment, the situation itself, or the semiotic resources available to them. For this reason, the concept of literacy or literacies - whether singular or plural - is necessarily multifaceted and contingent to specific social, cultural, political and historical circumstances.

In order to underscore the situatedness and contingency of literacy ${ }^{2}$ our reflections are grounded on four vignettes ${ }^{3}$ composed from the many stories we have been listening to or reading about in the papers and social media. The stories that inspired these vignettes capture the sense of displacement, loss or disorientation, but also hope and perseverance, connected to people's attempts to engage in remote education or simply exchange information using digital tools during the pandemic. These attempts are taking place against a backdrop of severe political and economic instability in Brazil, affecting people's lives on every level and forcing them to devise alternative strategies for study and work - often with recourse to digital technologies - as well as grappling with the challenge of juggling multiple chores, or negotiating with different views and expectations.

\footnotetext{
${ }^{1}$ It is always important to bear in mind professor Canagarajah's reservations about the use of "context", as the word may not a'dd much to the translingualism debate he proposed during a minicourse at Universidade de São Paulo in 2005. Indeed, the concept may appear too vague or abstract to make a significant theoretical contribution to this debate. However, in this paper, we opt for the use of the word as a tool for structuring our discussion of literacy/language amid the Covid crisis.

${ }^{2}$ Our option for the singular does not imply an understanding of language as unitary but, much on the contrary, as multiplicity, similar to Bakhtin's view of language as a heteroglossic phenomenon.

3 These vignettes are entirely fictional, based on Covid-19 news and personal stories that have reached us. Therefore, any similarity to actual persons or events, is purely coincidental. All names, characters, and incidents portrayed in the vignettes are fictitious. No identification with actual persons is intended or should be inferred. Furthermore, the choice of the first or third person singular in narrating them is purely stylistic.
} 
The use of fictional vignettes for problematizing literacy in this context of unprecedented instability is thus justified by the fact that, as literacy researchers we are less interested in defining the concept ${ }^{4}$ of literacy than investigating the circumstances in which it occurs. In our view, conceptualizing literacy in terms of its situatedness or circumstantialities helps us account for a wide array of meaning making processes, like the ones the characters of our vignettes resort to. We analyze them within a theoretical framework comprising authors as diverse as Biesta (2010, 2015a, 2015b), Deleuze and Guattari (2000, 2003) and Sousa Santos (2019, 2020). We also rely on authors that focus on literacy (especially digital, critical and emotional), such as Barcelos (2015), Junqueira; Buzato (2013), Lankshear and Knobel (2008), Matthews (2006) and Menezes de Souza (2019a, 2019b) among others.

\section{Ana plays it by ear}

Since the Covid-19 epidemic led to school closure, Ana, an English teacher at a public elementary school, has been feeling lost and unsure whether in-person instruction can be adapted to remote learning. She feels as if she is having to play it by ear, reinventing herself in order to cope with the arduous tasks of online teaching. She knows that not all her students have computers and access to highspeed Internet at home. Most of them can only stay in touch with her using theirparents' smartphones, like Oscar. Some of her fellow teachers do not have computers or Internet access, or sufficient digital literacy to prepare online classes. Owing to poor Internet access on the part of teachers and students, school administrators have asked teachers to record video lessons for broadcasting on the local TV channel. Besides that, students or their parents are expected to pick up print materials from school once a week, prepared by their teachers. On completion of their assignments, students take them to the school's office, where teachers will collect and grade them. In order to provide feedback and give students the opportunity to ask questions, Ana started a Whats App group with students, parents and some fellow teachers. She seems to have mixed feelings about the app, concerning its capacity to promote learning or simply improve interaction with herpeers or students. Seeing that her students are too young to have their own mobile phones, it is her students' parents who text her most often. She feels that some parents

\footnotetext{
${ }^{4}$ Useful as it may be, a concept for Deleuze and Guattari (2003) is just a concept, similar to a vector, without a subject or object apart from itself. Hence, their emphasis on the analysis of jurisprudence, or the circumstances that favor the emergence and consolidation of concepts.
} 
participate eagerly and come to better understand how the school works - which she feels is one of the positive aspects of the process - assisting their children in difficult tasks and passing on their children's and their own queries to the teacher. These range from simple technical questions to the English syllabus ones, and often point to difficulties pertaining not only to digital literacy, but literacy in general: 5 for example, how to navigate the app, access course materials and turn in assignments, upload files or download and sign up to the app or learning platform. On the one hand, she believes this kind of parent involvement has a positive effect on her students' progress. In addition, the use of apps, videos and online platforms can increase their exposure to the English language and facilitate communication with theirpeers. On the other hand, less than $10 \%$ of her students are regularly accessing the learning platform. Also, she fears that some of her students do not fully understand the language used in the instructional videos. At the end of the day, she has qualms about the efficacy of digital resources, and queries whether her students are actually learning English.

A shift from physical to online classes often means adapting traditional educational methods and tools to the online environment, at least for those teachers and students who can afford digital access. This seems to be the case of Ana, the primary school teacher from the vignette above, who can combine different resources such as printed materials and video lessons and also resort to a variety of digital technologies for communicating with her students, unlike some of her colleagues and students' families who either lack the resources to go online or the level of literacy to complete online tasks. A recent survey conducted by the National Union of Municipal Directors of Education (UNDIME) and the National Council of Secretaries of Education (CONSED) concerning the challenges schools in Brazil are facing to offer distance education indicates that $79 \%$ of Brazilian students say they have Internet access, but only $46 \%$ have access to the World Wide Web through their cell phones. These findings are corroborated by another survey conducted by Datafolha, Itaú Social, Lemann Foundation and Imaginable Futures: 95\% of interviewed families claim that they access the Internet through their cell phones. ${ }^{6}$

\footnotetext{
${ }^{5}$ She remembers one parent in particular who texted her because they could not sign in to the school app. Apparently this happened because the parent did not know what they were supposed to write under "filiação", which in Portuguese means one's parents' names and nationalities.

${ }^{6}$ Available at: https://www.itausocial.org.br/noticias/74-dos-alunos-das-redes-publicasrecebem-algum-tipo-de-atividade-nao-presencial-durante-a-pandemia/. Retrieved on: Jul. 29, 2020.
} 
What these findings suggest is that a significant number of teachers and students do not have access to the unequivocal opportunities provided by the Internet and the digital world. Having good computers or smartphones, as well as high speed Internet is not the case of most young Brazilian learners, which leads Coll, Mauri and Omrubia (2010, p. 71) to conclude that in Brazil "the incorporation of information and communication technologies (ICTs) in education is, therefore, far from presenting a scenario as homogeneous as one would sometimes suppose", as if the benefits of ICTs extended equally to all.

For most Brazilian public schools, access and use of technology are limited or non-existent. This is a consequence of the high number of schools, teachers and students in Brazil and the resulting elevated cost of providing school support "in the context of inadequate distribution of basic resources such as school meals and physical infrastructure" (JUNQUEIRA; BUZATO, 2013, p. 3). These authors also mention "the history of the dilapidated public education system and teachers' weak professional preparation" (JUNQUEIRA; BUZATO, 2013, p. 10) as difficulties and inequalities in Brazilian education with respect to technology use. We understand that access to technology "is just a small part of a much more complex problem” (JUNQUEIRA; BUZATO, 2013, p. 3), but we agree with Buzato that we need to talk about inclusion, whether social or digital, "from inside and outside, as included and excluded" citizens (BUZATO, 2010, p. 284).

The Covid-19 pandemic seems to have exposed and aggravated Brazil's social and digital inequalities. These are not new at all. Several Brazilian research studies and publications have on numerous occasions indicated school problems concerning the lack of technological infrastructure. Ribas (in press) conducted a bibliographical research between 2017 and 2018, aiming to investigate the implementation of English language teaching practices incorporating digital technologies in Brazilian schools. Results from this research suggest that although the use of digital technologies is associated with an increase in students' motivation and engagement in English classes, as well as innovative teaching for foreign language teachers, research conducted in public schools shows the obstacles teachers and students face when dealing with technology in language learning, among which: technical problems in the implementation of computer mediated English lessons, for example lack of computers, wi-fi or Internet connection; 
the traditional school culture, based on premises such as: the role of teachers as transmitting knowledge and students as uncritical, passive knowledge consumers, in addition to teachers often working on their own, without institutional support to carry out any educational project.

This traditional school mindset prevails even in remote teaching and learning situations, as is the case of Ana, the teacher from the vignette above. It is her role to prepare and grade tasks, as well as starting and managing Whatsapp groups for her students, who are considered as mere recipients of knowledge. This is characteristic of what Deleuze and Guattari (2003, p. 15) term "an arborescent culture", based on centered, "hierarchical modes of communication and preestablished paths" (DELEUZE; GUATTARI, 2003, p. 21), which has caused too much suffering and never really helped us to thoroughly understand multiplicity. Instead, they suggest that we substitute a rhizomatic mode of thinking for this arborescent model. "The tree is filiation, but the rhizome is alliance, uniquely alliance. The tree imposes the verb 'to be', but the fabric of the rhizome is the conjunction, 'and...and... and...'. This conjunction carries enough force to shake and uproot the verb 'to be"' (DELEUZE; GUATTARI, 2003, p. 25); unlike trees,

the rhizome connects any point to any other point and its traits are not necessarily linked to traits of the same nature: it brings into play very different regimes of signs, and even nonsign states $[\ldots]$ the rhizome is an acentered, nonhierarchical, nonsignifying system without a General and without an organizing memory or central automaton, defined solely by a circulation of states (DELEUZE; GUATTARI, 2003, p. 21).

The authors' reference to regimes of signs suggests the possible relevance of the concept of rhizome to studies about language learning and technologies. It seems that linguists, applied linguists and literacy scholars have been unable to stop searching for "roots" or to conceive of "nonsignifying systems without a General". Rather than investigate language in terms of its "internal structural elements", Deleuze and Guattari (2003, p. 8) suggest instead that "a method of the rhizome type, on the contrary, can analyze language only by decentering it onto other dimensions and other registers. A language is never closed upon itself, except as a function of impotence". It might be more realistic then to analyze language as comprising "semiotic chains". For Deleuze and Guattari, 
a semiotic chain is like a tuber agglomerating very diverse acts, not only linguistic, but also perceptive, mimetic, gestural, and cognitive: there is no language in itself, nor are there any linguistic universals, only a throng of dialects, patois, slangs, and specialized languages (DELEUZE; GUATTARI, 2003, p. 7).

Within this multitude of languages, "semiotic chains of every nature are connected to very diverse modes of coding (biological, political, economic, etc.) that bring into play not only different regimes of signs but also states of things of differing status" (DELEUZE; GUATTARI, 2003, p. 7). This is why Deleuze and Guattari defend a rhizomatic method of investigation to "decenter language onto other dimensions and registers", which underscores the entanglement of language in matters as diverse as religion, education, environment, public health, feminism, globalization, technology, race, immigration, among many others.

It appears that digital technologies such as messaging apps and social media are compatible with the rhizomatic logic of 'and...and...and...' - which, as we will see below, Deleuze and Guattari (2003) call nomadic thought - in the sense that they call for horizontal relations and multiple connections or assemblages among users, making it possible to conceive of education in less hierarchical terms. However, these technologies are sometimes deployed in educational contexts marked by a traditional, top-down, arborescent logic, which seems to be the case in the vignette above. This suggests a mismatch between the rhizomatic logic of digital technologies and the institutional, arborescent use to which they are being put, causing remote teaching to fall short of the expectations of teachers, students and society at large.

Ana's school, like all other Brazilian public schools, shifted to remote teaching mediated by digital technologies with the hope of salvaging the academic year. To some, the deployment of digital technologies represents a quick-fix solution, until our lives can get back to normal, or the status quo is restored. The problem, according to Paul Reville, ${ }^{7}$ Professor of Practice of Educational Policy and Administration at Harvard Graduate School of Education, is that the status quo was not serving all American children fairly. In order to learn, Reville states that "children need equal access to

\footnotetext{
${ }^{7}$ Available at: https://news.harvard.edu/gazette/story/2020/04/the-pandemics-impacton-education/. Retrieved on: Oct. 28, 2020.
} 
health care, food, clean water, stable housing, and out-of-school enrichment opportunities, to name just a few preconditions", and that schools should be working "on equitable access to educational technology as a way to close the digital-learning gap". Not much new under the sun; this suggests that we have been grappling with the same worldwide problems all along, most of which related to social and economic inequities. This digital-learning gap, as well as the lack of preconditions mentioned by Reville, has just been highlighted by digital technologies. The best that can come of the Covid-19 crisis, according to Reville, is "a new paradigm shift in terms of the way in which we look at education".

Perhaps such a paradigm shift could entail imagining new ways of doing, conceptualizing and researching literacy, revising the role of literacy in remote and in-person education, or formulating relevant literacy problems for pandemic and post-pandemic times. Have literacy studies somehow been playing a part in the maintenance of social and economic inequities? How can they help redress them? In what ways can the rhizomatic logic of 'and... and... and...' foster new forms of understanding and investigating literacy, bringing into play different regimes of signs, and "even nonsign states", with a view to "decentering language onto other dimensions and registers"? Arguably some of the challenges or difficulties mentioned in the vignette could supposedly stem from a lack of literacy; but what does the notion of lack or the undue emphasis on it presuppose? Or what does thinking in terms of a lack prevent us from seeing? How can we bridge the gap between formal education and informal settings, or what can we learn from research on out-of-school literacies (HULL; SCHULTZ, 2001)? What are the strengths and weaknesses of conceptualizing literacy or literacies in terms of "new", "multi", "digital", or "critical"? The following vignette gives us an opportunity for further reflection on these issues.

\section{Juggling parenting, academic and household chores and...}

My name is Celina. I have been working in a public university for 12 years. In 2017, I gave birth to a baby girl and since then my professional and personal life has been upside down. Taking care of a child and being a teacher and researcher bring everyday challenges, but I could handle them quite well thanks to the support of my mother-in-law and the nursery school teachers. However, since the Covid-19 outbreak all the schools in Brazil have been closed for the last four months. So, now, besides 
working as a language educator, I have to be there for Luisa full time. Although I was already familiar with technology in teaching, as well as teaching online classes and organizing virtual meetings, now the picture is completely different. A regular day in my life involves cooking for my family, washing the dishes, changing diapers, washing my hands a thousand times a day, entertaining Luisa along with checking emails, answering $W$ hatsapp messages from my friends, students and neighbours, attending virtual meetings with co-workers and graduate advisees, conducting remote classes, reading and writing papers. One of my advisees is Ana, an elementary English teacher, who has been developing her PhD thesis on strategies to help marginalized students learn English (against all odds) in pandemic times. My busband is also working remotely, so we share the responsibilities of taking care of Luisa and the house. However, sometimes we have to attend online meetings at the same time, so the task of looking after Luisa is up to me. Playing with dolls while attending online meetings has become a routine in my life. I have been multitasking (and stressed) at the highest level. Sometimes I feel really guilty: I am neither being a good mother nor a goodprofessional.

Like Ana, the teacher from the previous vignette, Celina seems to be able to cope with digital technologies. Both could be considered digitally literate, either in a narrow or a broad sense (FREITAS, 2010). In a narrow sense, digital literacy is understood as technical knowledge or ability to use digital tools. Strictly speaking, digital literacy thus means using technology in a merely functional way. In a broad sense, however, digital literacy encompasses the sociocultural, historical and political contexts surrounding the use of technology. It entails a

set of necessary skills so that an individual understands and uses information in a strategic and critical way, in multiple formats, from a variety of sources, from computer-internet, being able to achieve his/her purposes, which are socially and culturally shared. ${ }^{8}$ (FREITAS, 2010, p. 339-340)

According to Freitas (2010), a digitally literate person is able "to associate pieces of information, to have a critical perspective on them, transforming them into knowledge" (p. 348).

For Lankshear and Knobel (2008, p. 258), digital literacies (rather than literacy), "involve the use of digital technologies for encoding and accessing

${ }^{8}$ This and all the other quotes in Portuguese have been translated into English by us. 
texts by which we generate, communicate and negotiate meanings in socially recognizable ways". In common with Lankshear and Knobel (2008) and Freitas (2010), Martin (2008, p. 167) also underscores the social aspect of digital literacy and, like Freitas, emphasizes its role in the construction of knowledge:

Digital Literacy is the awareness, attitude and ability of individuals to appropriately use digital tools and facilities to identify, access, manage, integrate, evaluate, analyze and synthesize digital resources, construct new knowledge, create media expressions, and communicate with others, in the context of specific life situations, in order to enable constructive social action; and to reflect upon this process.

These definitions of digital literacy all include technical, strategic, multiple and critical abilities in the use of technology, as suggested by verbs such as "associate", "use", "identify", "analyze", "manage", "communicate", "negotiate" and "transform", used to name the necessary skills for the digital era. However, it is interesting to notice that none of the definitions above touch upon the emotional component involved when using digital resources. Therefore, to achieve a better understanding of digital literacy, we understand it is also important to take emotional literacy on board.

Barcelos (2015, p. 66) notes that although we tend to stress the rational component involved in the task of teaching, "emotional literacy runs through everything we do and think of, since cognition and emotion are inseparable". Based on Matthews, for whom emotional literacy incorporates "a view of emotions being experienced individually and arising out of social situations and interaction with others" (MATTHEWS, 2006, p. 43), Barcelos defines it as "a set of emotional practices related to how individuals and groups of people read and write the world emotionally in their social contexts" (BARCELOS, 2015, p. 71). It is about how we understand our surroundings and give meanings to them, in a process where emotions always arise.

For Barcelos and Matthews, emotional literacy should not be seen only as individualistic, but also as a social process. Similarly, Weare (2004) also defines emotional literacy in terms of individual and social abilities. Self-knowledge, understanding and managing emotions, and understanding social situations and making relationships, according to Weare (2004), point 
to the social aspects of emotional literacy. When it comes to relationships, "experiencing empathy for others" (WEARE, 2004, p. 4) is what we believe should be considered in remote working, not only empathising with others, but also with ourselves. While the Covid-19 pandemic means high productivity for some, especially men, for others, like women with children under four years old, the pandemic represents a daunting challenge. About the impact of Covid-19 on academic mothers, Staniscuaski et al. (2020) point out:

for many researchers, the release from teaching and administrative activity means more time for independent work. In contrast, parents of young children for whom school has been cancelled are facing uniquely challenging responsibilities (...) Instead of writing papers, they are likely to devote time to homeschooling children and doing household chores. For those who have not yet leaked from the pipeline and are struggling to keep their careers on track, these months of heavier duties may increase the distance between them and their male and childless peers (p. 724).

An article from El País ${ }^{9}$ has also stressed the overload and demanding situations characterizing the routine of women nowadays, who are being forced to work around the clock to handle their careers and family responsibilities, as is the case of Celine in the vignette. According to the article, even in situations where women and men share household and parenting responsibilities, it is women who have the heaviest mental workload, having to organize their children's homework, remember their passwords to access virtual learning platforms, among other tasks. The article concludes that for men, the only thing that has changed in their routine is that they now have to do the shopping more often.

Women's predicaments during the Covid-19 pandemic remind us that literacy, whether emotional or digital, always has to be conceptualized in relation to specific social and cultural settings: for example, taking the gender gap in a particular geographical and historical context into account. Because of its locatedness in a specific social context, and the fact that

\footnotetext{
9 Available at: https://brasil.elpais.com/smoda/2020-05-28/trabalho-de-madrugadaporque-nao-dou-conta-de-tudo-em-casa-a-nova-normalidade-massacra-as-mulheres.html. Retrieved on: Jun. 5, 2020.
} 
it is "profoundly influenced by the context or environment in which we function" (FAUPEL, 2003, p. 6-7), emotional literacy can only be appraised in action, that is, in social interactions (MATTHEWS, 2006). In times of pandemic, emotional literacy is "a necessary literacy so that we can survive a crisis in values, chaos, violence and intolerance that is often installed in classrooms, schools and society as a whole", and in face-to-face and online settings, we would add.

Working remotely in pre-pandemic times meant using technology to shorten the physical distance between Celina and her co-workers and students. It had a positive connotation since technology could be used as an asset to her job. Nevertheless, in pandemic times, working remotely now means tiredness and feeling lost and isolated, even in the virtual presence of others. This indicates that she will have to learn how to acknowledge the profound influence of emotions on the use of technology, if she wants to contend with the chaos that has "shaken her values", to use Barcelos' words (BARCELOS, 2015, p. 71). A survey conducted by CONJUVE ${ }^{10}$ (National Board of Youth) with 33,688 students between 15 and 29 years old from all over Brazil indicates that the main challenges these students are facing to study from home are not restricted to lack of time, equipment or Internet access. Rather, these students claim that they lack emotional balance and organizational skills for remote learning. This implies that values such as cooperation, empathy and critique should be instilled, especially in these difficult times.

The Covid-19 pandemic is showing us that one's digital literacy can hardly be fully developed, and that we also have to take emotions and how they affect decision making on board. Still, however much digital or e-literacy is developed, ultimately some sort of illiteracy will always remain, given "the weakness and limitation of all knowledge, since it always represents the ignorance of other knowledges" (SILVESTRE, 2016, p. 116-117). ${ }^{11}$ The pandemic is a powerful reminder of the complexity and unpredictability of the world, as well as the importance of extemporization and the formulation of new meanings and provisional solutions when facing the unknown. Furthermore, we must bear in mind that "meanings (are) partial

\footnotetext{
${ }^{10}$ Available at: https://www.juventudeseapandemia.com/. Retrieved on: Oct. 12, 2020.

${ }^{11}$ Silvestre appears to endorse Sousa Santos' (2019) reminder of the limitations of Western, hegemonic, scientific knowledge and the importance of an "ecology of knowledges".
} 
and incomplete, since they are localized, ideologically marked and always liable to change" (JORDÃO, 2007, p. 21). This means that we will never fully grasp reality in its entirety, since our understanding of the world is "constantly constructed in our discursive relationships with others" (p. 21). Therefore, any explanations and solutions will have to be sought collectively in constant, protracted, multilateral and, as we will see in the next vignette, delicate negotiations with different points of view.

\section{4 ...and social media}

Since the onset of the pandemic, I've been spending more and more time on social media. I'm in at least a dozen Whatsapp groups, which means that if I wanted to read all the messages, this would take up a lot of my time. That is why I don't. Most of the time I just scroll down the screen of my smartphone for a quick update. But there are two conversations in particular that caught my attention, because they both raise the question of conflict and how people deal with it, as well as the difficulty in reaching a common set of interests. The first is from one of my Whatsapp groups with friends:

\section{PICTURE 1 - Whatsapp conversion 1}

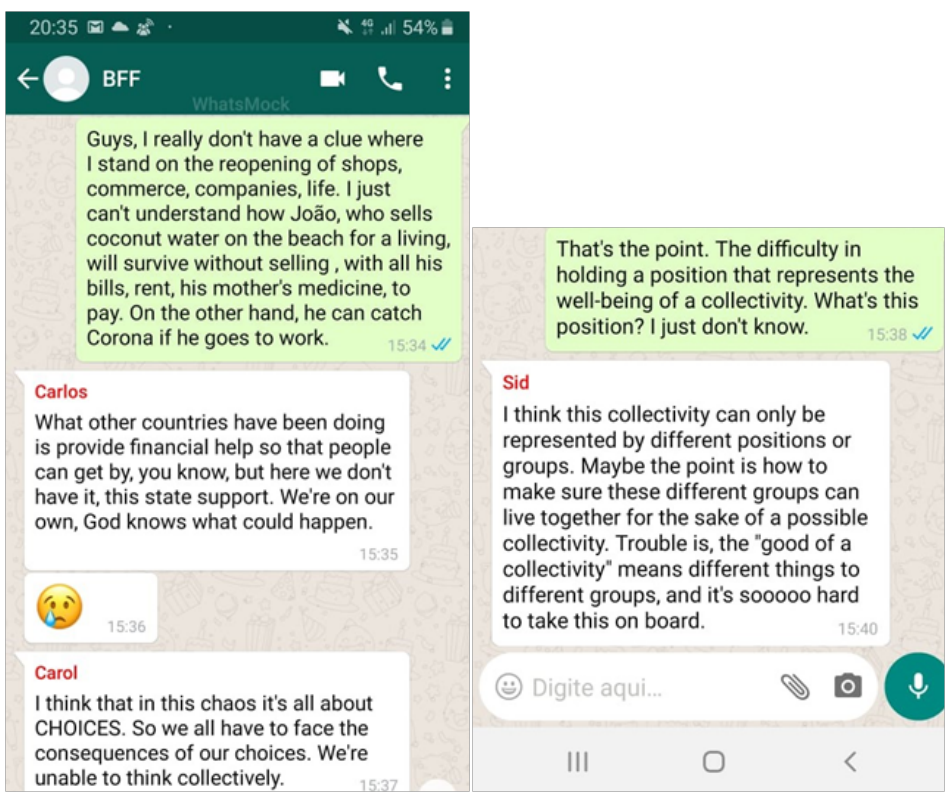

Source: Authors' own elaboration 
The second conversation is from a Whatsapp group with neighbours in the building where I live. One of the members, male, middle-aged, has posted a short video featuring a Catholic priest holding Our Lady's statue for a blessing protecting against Covid. The video is followed by a message forwarded by him:

\section{PICTURE 2 - Whatsapp conversation 2}

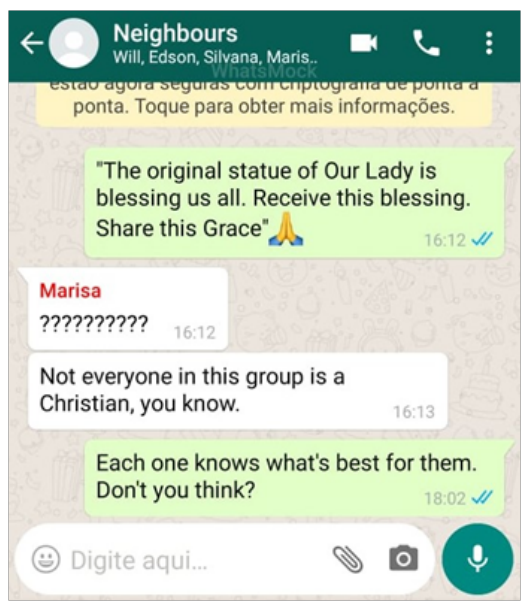

Source: Authors’ own elaboration

In addition to these, a meme on Facebook has recently caught my attention too:

$$
\text { PICTURE } 3 \text { - Meme }{ }^{12}
$$

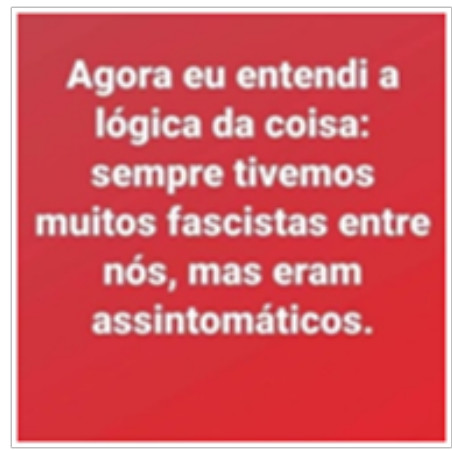

Source: https://www.facebook.com/bolsonaronunca/ posts/d41d8cd9/2359624894342575/

12 "Now I got it: we've always had many fascists around us, but they were asymptomatic". 
I wonder whether some of my Facebook friends are asymptomatic fascists. I should probably unfriend them. And yet I can't help thinking that these virtual communities are turning into little bubbles of like-minded people who are unable to handle conflict or difference.

These messages from Celina's Whatsapp groups suggest that digital technologies make it possible for people to express their views on a wide range of subjects in relatively safe digital environments where they do not have to compromise, or risk losing face. While often finding refuge in virtual "bubbles of like-minded people" among whom conflict is unlikely to arise, people sometimes participate in groups where different opinions may become a source of serious disagreement. This means that in this day and age of virtual proximity, people's tastes, political and religious views or sexual orientation can hardly be taken for granted, as evinced by the second Whatsapp conversation.

Both conversations suggest that dissenting opinions could lead to conflicts which cannot be avoided or settled. It remains to be seen how to design common goals for the supposed "well-being of a collectivity made of multiple subjectivities", as someone from the first Whatsapp conversation points out. How can we remedy our "inability to think collectively", mentioned in the first conversation? Or acknowledge our multiple subjectivities and at the same time find a "a position that represents the well-being of a collectivity"? In other words, can common objectives be pursued by individuals living in societies fraught with political, religious and ideological conflict and dissent? How can this conflict be negotiated in a way that not only hegemonic interests are served? Or so that the growth of fascistic groups can be curbed? Can different groups enter this negotiation without having to homogenize their internal differences, or to compromise too much? On what terms - rather than whose terms - is democracy attainable?

One of the language and literacy theorists interested in some of the questions above is Menezes de Souza (2019a), who stresses the necessity of critique. His understanding of critique informs his conception of decoloniality ${ }^{13}$ which, in turn, seems to overlap with his conception of critical

\footnotetext{
${ }^{13}$ A decolonial attitudeanalyzes and criticizes the injustices and inequalities created by modernity. Also, according to Menezes de Souza (2019b, p. 7) "the decolonial theories or epistemologies of the South are theories against universality", against efforts to treat
} 
literacy, which we subscribe to. According to him, critique does not entail the pursuit of "true" or "right" knowledge, but begins with the realization that knowledge is always partial, incomplete. This realization can develop into a critical awareness - which, as we see it, is at the core of his conception of critical literacy - of "the import of one's locus of enunciation", ultimately leading to one's "unlearning learned ignorance", or becoming aware of the limitations of one's knowledge about other forms of knowledge. According to Menezes de Souza (2019a, p. 38), acknowledging the existence of diverse, multiple loci of enunciation and how they shape different, conflicting readings and interpretations is at the heart of decolonial thought:

Working through these loci, reading them against their histories, their epistemologies and the power relations in which they are immersed and confronting them with one's own histories, epistemologies and power relations is what decolonial border thinking is about.

Critique thus calls for a recognition of the situatedness of our loci and the limits of all knowledge, since "it always represents the ignorance of other knowledges", as also suggested by Silvestre (2016) in the previous section.

Being critically aware of different loci of enunciation could help understand how conflicts such as the one depicted in the second conversation may arise, or how people come to join social "bubbles". Also, it can help us realize how our meaning making processes are necessarily connected to our loci, and recognize their coexistence with a multiplicity of interpretations. In this context, there is no question of "finding a position that represents the well-being of a collectivity" considering its multiplicity of political, religious and social affiliations.

Multiplicity, as Deleuze and Guattari (2003) point out, is at the origin of language and society. If there appears to be any cultural and linguistic homogeneity, it is always the result of a successful power operation, through which a particular individual or group of individuals seeks to impose their views on other groups and individuals. As Deleuze and Guattari (2003, p. 7)

every aspect of life in a homogeneous way. We agree with Menezes de Souza (2019b, p.7) that "what intends to be universal is, in fact, a local knowledge with a colonizing force" (MENEZES DE SOUZA, 2019b, p. 7). We must consider that "we are always saying something from a specific position, which is permeated by particular stories" (2019b, p. 6). 
suggest, "there is no mother tongue, only a power takeover by a dominant language within a political multiplicity" which must be harnessed for the benefit of hegemonic groups that champion neoliberal capitalism. Thus "language is made not to be believed but to be obeyed, and to compel obedience (...) A rule of grammar is a power marker before it is a syntactical marker" (2003, p. 76).

The political nature of language thus justifies the overriding importance of critical literacy and decolonization studies that stress the complicitness of language practices with power, ideology and capitalism. In this sense, the "inability to think collectively" mentioned in the first Whatsapp conversation is, first and foremost, a political inability to think collectively; one that calls not for one, but several positions that represent the "well-being of a collectivity" not only fraught with "political, religious and ideological conflict", but which can also thrive on it, able to negotiate differences.

Joining "bubbles of like-minded people" and unfriending anyone posting fascistic comments on social media hardly seem to be the best courses of action for a democratic society. After all, according to Deleuze and Guattari (2003, p. 214), fascism runs though the whole social, molar fabric: "rural fascism and city or neighborhood fascism, youth fascism and war veterans' fascism, fascism of the Left and fascism of the Right, fascism of the couple, family, school and office". Deleuze and Guattari warn that "what makes fascism dangerous is its molecular or micropolitical", or the fact it proliferates into microfascisms. Hence their warning that "it's too easy to be antifascist on the molar level, and not even see the fascist inside you, the fascist you yourself sustain and nourish and cherish with the molecules both personal and collective" (2003, p. 215). If there can be a fascist within each and every one of us, the question is how to stifle it, or keep it "asymptomatic", as the meme suggests.

The search for answers to this question, according to Deleuze and Guattari $(2000 ; 2003)$, should necessarily take account of desire. For them (2003, p. 215),

desire is never separable from complex assemblages that necessarily tie into molecular levels, from microformations already shaping postures, attitudes, perceptions, expectations, semiotic systems, etc. Desire is never an undifferentiated instinctual energy, but itself results from a highly developed, engineered setup rich in interactions. 
On the relatioship between desire and the social, Deleuze and Guattari contend that "desire is part of the infrastructure" (2000, p. 104), that is, the production of desire is coextensive with the social production. While one can consciously uphold the interests of one's own class, one can unconsciously reinforce "one's submission to a dominant class" (2000, p. 104). Indeed, they claim (2000, p. 104) that

A form of social production and reproduction, along with its economic and financial mechanisms, its political formations, and so on, can be desired as such, in whole or in part, independently of the interests of the desiring-subject.

It should therefore come as no surprise that Hitler literally sexually aroused fascists, just as "a banking or stock-market transaction, a claim a coupon, a credit, is able to arouse people who are not necessarily bankers. And what about the effects of money that grows, money that produces more money?" (DELEUZE; GUATTARI, 2000, p. 104). Given the fact that social production is rooted in desire - consequently, implementing social change involves reinventing desire - and assuming that Deleuze and Guattari's critique of capitalism has never been more relevant in times when salvaging the economy is given priority over saving human lives or preserving the environment, critical literacy researchers could set out to investigate this coextensiveness between desire and social production, asking such questions as: what kind of society nurtures a deep and lasting violence against women, gays or black people, and the desire for firearms or capital punishment? Difficult though they may seem, these are necessary questions that remind us of our accountability as researchers, and the necessity of a critical investigation of the "metadiscursive regimes" (MENEZES DE SOUZA, 2019a) which regulate knowledge production. As critical literacy researchers, we cannot lose sight of the political, economic, social and emotional implications of language in the production of desires, some of which could be too closely related to a eurocentric framework that reinforces the very social and economic inequities we are struggling against. This is further developed in the next vignette. 


\section{Can I have the Wi-Fi password, please?}

Oscar's dream is to be an engineer. Sobe has been studying hard to enter a public university. Even though his classes have been cancelled due to the Covid 19 pandemic, he has not stopped studying. His teachers are posting online tasks and he will do anything to try to complete them. He does not have a computer or a laptop, or even Internet access at home. But he does have a smartphone, so everyday he goes to a local bakery shop, buys some cheese bread, and stays there the whole morning or afternoon taking notes while connected to the the Wi-Fi network of the shop. Uploading files from his cellphone is sometimes hard and slow, and many of his colleagues are having similar diffculties, even some teachers. On many occasions, his English teacher, Ana, is not able to open his files and asks for his assistance. He realizes he is not the only one baving trouble with technology.

Despite not having access to the Internet or a good computer, Oscar is doing whatever he can not to stay behind. He even manages to help his teacher Ana perform online tasks. This is testimony to the collaboration and sharing of expertise, characteristic of the new digital technology mindset: on the one hand, Ana is guiding him in his studies by preparing online classes, on the other hand he assists her in the conversion of files, among other technological tasks. Could this pave the way for more horizontal relationships in education, conceived of in less hierarchical terms, following a collaborative, rhizomatic logic?

There are a number of theorists who point to a number of social, political and educational advantages of digital technologies. According to Wellings and Levine (2009), information and communication technologies can foster inclusion. In addition, they expand the access to education, virtual communities and expertise; engage learners in learning and content creation; enable personalized instruction; support learner's development in literacy and mathematics, among other advantages. Also, Coll, Mauri and Omrubia (2010) highlight the mediating potential of digital technologies in education, as well as the ways in which they have transformed traditional ways of access and dissemination of information. This is due, according to Lankshear e Knobel (2006), to a new ethos that has been installed with digital technologies - "an emerging and evolving mindset" that focus on "participation over publishing, distributed expertise over centralized expertise, collective intelligence over individual possessive intelligence, 
collaboration over individuated authorship, dispersion over scarcity, sharing over ownership (LANKSHEAR; KNOBEL, 2006, p. 29).

Warschauer (1998) advocates the importance of understanding digital technology from a critical approach, which "sees technology as neither a neutral tool nor a determined outcome but rather as a scene of struggle between different social forces" (WARSCHAUER, 1998, p. 758). This struggle could be accentuated by an increase in the digital gap during the Covid-19 crisis, with those who have the best technological apparatus dictating the terms of literacy, and those who do not challenging the status quo. Therefore, economic, social and political issues must be examined when assessing the impact of technologies on teaching and learning, how the sociocultural context of institutions and communities affect learning, and how digital literacy practices are locally interpreted. For Santos et al. (2018, p. 33), such a critical approach "accounts for a more nuanced social view on how individuals appropriate and shape different technologies when engaging in digitally mediated activities". Such a critical approach, we could add, should also take into consideration the fact that in Brazil a significant number of public school students, like Oscar, cannot afford computers or high speed Internet access to fully engage in remote learning, and investigate the political and economic reasons for this.

Sadly, the Covid-19 pandemic is spotlighting Brazil's long-standing social and digital inequalities. Junqueira and Buzato (2013) investigated the use of digital technologies in Brazilian public schools for the last forty years. They conclude that overall, the Brazilian experience has been heterogeneous, with a vast array of difficulties outnumbering a few successful initiatives. The latter are largely due to teachers' own efforts to use digital technologies in the classroom, despite receiving little assistance from the State. The picture below gives an example of public school teachers using their creativity for teaching remotely in times of Covid-19 crisis: 
PICTURE 4 - Public school teacher recording a video lesson

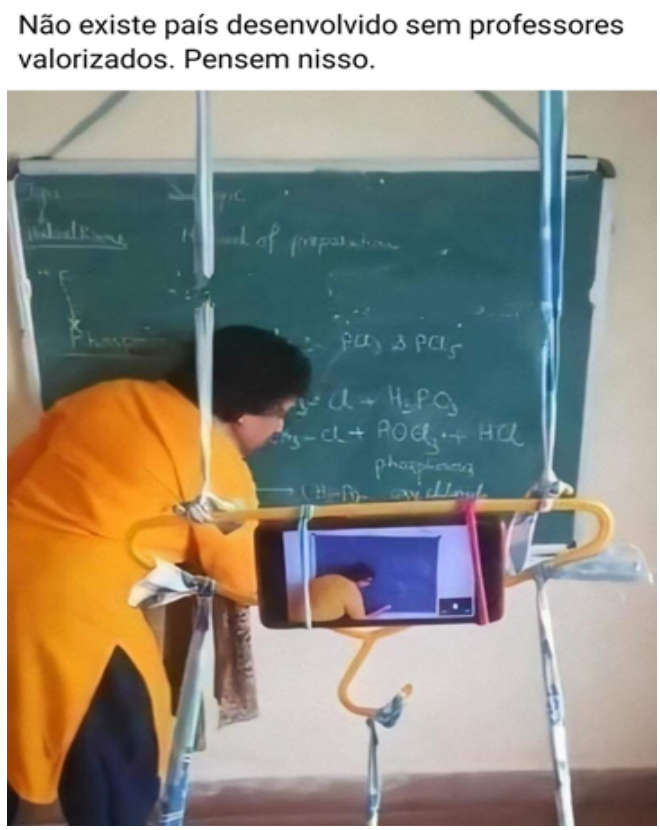

Source: https://twitter.com/quebrandootabu/status/1272514198635864067

The picture above illustrates "how neoliberal capitalism has incapacitated the State to respond to emergencies" (SOUSA SANTOS, 2020, cap. 4). As Sousa Santos (2020, cap. 4) suggests:

The three principles of regulation of modern societies are the State, the market and the community. In the last forty years, the principle of the market has been given absolute priority over the State and the community.

Neoliberalism ${ }^{14}$ disseminates market values to all institutions, including the educational field, and prizes the notions of individual choice and freedom (CHUN, 2013). The idea of the neoliberal, self-governing citizen capable of self-realization, self-regulation and entrepreneurship

\footnotetext{
${ }^{14}$ Neoliberalism (...) is an ideological and structural apparatus that promotes a free-market economy by privatizing public services, creating a flexible workforce, and increasing individual and institutional accountability for economic success, while reducing social services and producing disparities between the rich and the poor (KUBOTA, 2014, p. 12).
} 
(CHUN, 2013) is, for us, the most pervasive feature of the neoliberal discourse, which influences Brazilian educational policies, such as the Common Core Curriculum. ${ }^{15}$ The emphasis on "the development of individual competencies in service of economic growth" (KUBOTA, 2014, p. 13) underlies the pedagogical principles of such policies, as can be seen through the repeated use of words such as "autonomy", "determination", "responsability", and "resilience" in the Common Core Curriculum. These neoliberal policies can become so inculcated among people like Oscar that they believe they are the only ones responsible for achieving professional success against all odds, and cannot envision other ways of life. Neoliberalism becomes naturalized, and should thus be challenged and resisted. In this sense, we agree with Chun (2013, p. 28):

It is important to counter neoliberalization and its discourses that champions the so-called free market as the only social mechanism worthy of organizing and shaping our everyday interactions and experiences. What is at stake is how we can imagine and generate new ways of organizing our societies so that we can fully participate democratically to change existing options (CHUN, 2013, p. 86).

One way to counter neoliberalism may be to reflect on its harmful effects on language teaching and learning and education in general, making the invisible ${ }^{16}$ more visible. According to Sousa Santos, the Covid-19 pandemic and the ensuing quarantine "are revealing that alternatives are possible, that societies adapt to new ways of living when this is necessary and felt as corresponding to the common good" (SOUSA SANTOS, 2020, cap. 5). Some of these adaptations can be seen in Brazilian schools, as the first vignette suggests. Public universities are also preparing their teachers and students by offering workshops on distance education, digital literacy, flipped classroom, active methodologies, to name a few. In addition, university policies assisting students in need of Internet access and equipment are also being formulated. Furthermore, teachers are sharing useful materials

\footnotetext{
${ }^{15}$ Base Nacional Comum Curricular.

${ }^{16}$ We believe that neoliberal discourses in educational policies are invisible when you do not read between the lines. Neoliberalism appropriates discourses based on such ideas as collaboration, collectivity, diversity and critique to perpetuate itself insidiously.
} 
and tips on how to use virtual learning environments (Moodle, Google Classroom, Edmodo) and other communication devices (Microsoft Teams, Google Meet, Whatsapp) with their students. Yet it remains to be seen whether all these actions can promote good education, rather than effective education (BIESTA, 2015b).

According to Biesta (2015b, p. 81), "the duty of education is to ensure that there is good education for everyone everywhere", instead of effective education. While the latter is concerned about achieving certain desired - and we could add eurocentric - results, the former acknowledges the purposes of education, ${ }^{17}$ that is, the skills and values being taught and the kinds of students we are helping to educate. Moreover, good education, seen as a fundamental right that should be extended to all, entails educating all students, "all meaning all", as stressed by Paul Reville in the previous section. If this were the case in Brazil, and special attention were given to the "groups from the South"18 (SOUSA SANTOS, 2020, cap. 3), the following headlines would not have appeared in Brazilian newspapers:

Illiterate mother in Belo Horizonte quits picking up school materials for her son as she cannot help him with homework. ${ }^{19}$

In Ceará student waits for mother to get home from work to use her cellphone to study. ${ }^{20}$

As educators and language and literacy researchers, we cannot help the mother from the first headline or provide high speed Internet to all

\footnotetext{
${ }^{17}$ Biesta defines three main purposes of education: 1) the qualification of students, which "lies in providing them with the knowledge, skills and understandings and often also with the dispositions and forms of judgement that allow them to "do something"; 2) the socialization of students, which "has to do with the many ways in which, through education, we become part of particular social, cultural and political 'orders"' and 3) the subjetification of students - "the process of becoming a subject", that is, "ways of being that hint at independence" from existing orders, "ways of being in which the individual is not simply a 'specimen' of a more encompassing order” (BIESTA, 2010, p. 20-21).

${ }^{18}$ The South, for Sousa Santos (2020) is not a geographical space, but "a metaphor of unfair human suffering caused by capitalist exploitation, racial and sexual discrimination" (cap. 3).

${ }^{19}$ Available at: http:/ / avozdotriangulo.com.br/analfabeta-mae-desiste-de-pegar-materialda-escola-do-filho-em-bh-por-nao-poder-ajuda-lo/. Retrieved on: Dec. 2, 2020.

${ }^{20}$ Available at: https://www1.folha.uol.com.br/educacao/2020/07/no-ceara-aluno-esperamae-chegar-em-casa-pra-estudar-com-celular.shtml. Retrieved on: Dec. 2, 2020.
} 
our students. This is a social prerogative that should be upheld by the State. Public policies must guarantee that no student is left behind when it comes to information access. What we can do though is to create spaces of reflection in our classrooms and academic communities for investigating the reasons for the widening digital gap and related social and economic inequalities in Brazil. We could critically examine what happens inside our classrooms and whether they reproduce eurocentric categories of thought, valuing an "ecology of knowledges" (SOUSA SANTOS, 2019) that includes non-hegemonic forms of expression and knowledge, and support the decolonial fight of the oppressed and counter the domination of colonialism, capitalism and patriarchalism. As language and literacy researchers, we could also strive to think literacy anew, "off the beaten track", taking into account the variety and multiplicity of semiotic processes happening both online and offline. Who could imagine learning to speak Korean fluently by watching tutorials uploaded on video-sharing platforms? Creating and sharing 15-second videos to increase someone's popularity and earning a living? Watching online short movies for children based on adaptations of classics such as Odyssey, Hamlet or Romeo and Juliet, made with toy art? ${ }^{21}$ Or finding blogs devoted to storytelling ${ }^{22}$ in sign language?

These complex, intensely multimodal, hybrid - or nomadic, as Deleuze and Guattari (2003) would describe them - semiotic processes call for a coalition of literacy studies which can pave the way for the creation of smooth spaces of thought and expression, organized as a rhizome or multiplicity, as opposed to a root model (DELEUZE; GUATTARI, 2003), as discussed in the first vignette. Unlike representational thought, based on a closed equation (" $\mathrm{a}=\mathrm{a}=$ not $\mathrm{b}$ "), nomadic thought is grounded in an open equation of concurrence (“... $+\mathrm{a}+\mathrm{x}+\mathrm{m}+\ldots$...) which "synthesizes a multiplicity of elements without effacing their heterogeneity or hindering

${ }^{21}$ Brazilian artist Walmick de Holanda started making short movies based on literary classics during Covid-19 lockdown, to help friends who had run out of storytelling ideas for their children. Since then, he has been posting them on his social media. Available at: https://www.instagram.com/walmickdeholanda/?hl=pt-br. Retrieved on: Dec. 5, 2020.

22 The blog "Mãos aventureiras" was created by Brazilian university professor Carolina Hessel. Available at: https://mulheresnaciencia.com.br/maos-aventureiras-literaturainfantil-em-libras/\#: :text=Carolina $\% 20 \mathrm{Hessel} \% 2 \mathrm{C} \% 20 \% \mathrm{C} 3 \%$ A $\% \% 20$ Doutora $\% 20$ em,Literatura $\% 20$ Infantil $\% 2 \mathrm{C} \% 20$ Artes $\% 20 \mathrm{e} \% 20$ Filmes. Retrieved on: Oct. 12,2020 
their potential for future rearranging (to the contrary)" (2003, p. xiii). A nomadic approach to literacy and literacy studies thus acknowledges not only the fact that this multiplicity cannot be effaced, but also that it must be made or enforced. How?

According to Deleuze and Guattari (2003), by multiplying desire. Desire for Deleuze and Guattari always amounts to social production. The question thus for critical literacy researchers is how to engage people in meaning making processes in such ways as to produce more and more desire: the desire to value difference, to live and let live, and the desire for agency through creativity; the desire for establishing multiple connections and assemblages in a rhizomatic network; the desire for sustainability, for an ethical relationship with other living beings, for being at one with Pachamama; the desire for a radical overhaul of human relationships, fighting all forms of oppression based on race, creed, gender, age or sexuality; the desire for countering the excesses and harmful effects of capitalism (such as the ones that could befall indigenous populations in Brazil, among which the yanomami, whose ancient lands are falling in the hands of mining companies or landowners), coupled with the possibility of giving spiritual and psychic well-being priority over material wealth.

\section{Final words}

We wrote this paper out of curiosity; we were curious to investigate literacy practices and events occurring amid the Covid 19 crisis. Given our professional experiences and research interests, we were particularly interested in how formal schooling has been affected by the pandemic, though we also wanted to reflect on other sites of meaning production which we believe merit serious scholarly attention. Also, we wanted to reflect on the lessons we learned from the stories that inspired our fictional vignettes above.

One of these lessons is that reflection on the present crisis should be grounded in a perspective of language and literacy that emphasizes the situatedness, circumstantiality or contingency of literacy practices and thus underscores their multiplicity, be it in the form of diverse hybrid, multimodal meaning making processes such as the ones mentioned in the first vignette; of emotions and chores, as suggested in the second vignette; or of desires or social forces - which, according to Deleuze and Guattari (2000, 2003) 
are exactly the same - as in the third vignette. This means that for there to be social change, desires have to change and multiply.

The social change that we hope for is one towards the end of injustice, oppression, excessive materialism and environmental destruction. We hope these are not part of "the post-crisis new normal", ${ }^{23}$ which should not restore a normality characterized by social and economic inequities, as argued by Paul Reville above. We believe this new normal should be about questioning and changing the role of schools, teachers and students, and exposing the harmful effects of neoliberalism in the maintenance of social injustices. Sousa Santos (2020, cap. 4) views the neoliberal thinking as the current version of capitalism, and, in his words,

capitalism can survive as an economic model of production, distribution, and consumption, among others, but not as the only model and not as the model that dictates the logic of action from the State and society (...) this model ignores any logic of public service, thus it overlooks the principles of citizenship and human rights (SOUSA SANTOS, 2020, cap. 4).

Sousa Santos believes that "as a social model, capitalism has no future" (SOUSA SANTOS, 2020, cap. 4), therefore we should imagine ways of opposing it or thinking otherwise. The following meme ${ }^{24}$ hints at this possibility:

\footnotetext{
${ }^{23}$ The rhetoric of the "new normal" "contends that things will never be the same as they were before, so we have to adapt to a 'new world order' (ASONYE, 2020). Available at: https://www.weforum.org/agenda/2020/06/theres-nothing-new-about-this-new-normalheres-why/. Retrieved on: Jul. 29, 2020.

${ }^{24}$ This meme/pun alludes to the chorus of the song "A banda", by Brazilian composer Chico Buarque, and could be translated as "Watching the band pass singing about love". The wordplay is based on the words "watching" and "sale", which are homonyms in Portuguese.
} 


\section{PICTURE 5 - Meme 2}

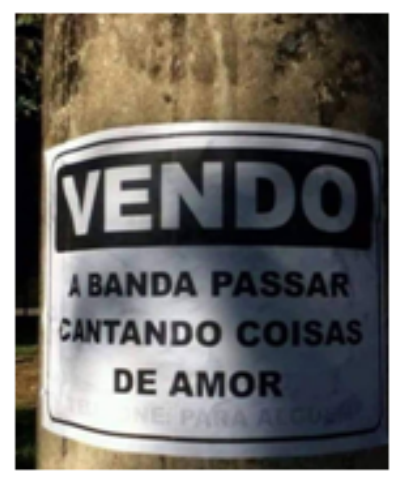

Source: https://br.pinterest.com/pin/461689399302896811/

The well-known chorus of Chico Buarque's song is a nostalgic reference to a time when consumerism, social and economic inequality and the devastation of the planet were not so rampant. The meme reminds us that there is more to life than the accumulation of wealth and that it does not all come down to profit, that there is always room for imagining otherwise; for the creation of meaning making spaces where new meanings, positions and desires can emerge as alternatives to neoliberal, capitalist hegemony.

Neoliberalism tends to treat all problems as technical. This, as Sousa Santos (2019) reminds us, is wrong. It does not seem sensible to view digital technologies as a panacea for all the problems teachers and students have been facing amid the Covid-19 pandemic, allowing them to salvage the school year. Although access to technology is crucial for the social inclusion of teachers and students and the development of their digital literacy, we understand that granting students and teachers full access to digital resources does not by any means guarantee that they will be able to grapple with the challenges of online education. In the first vignette, for instance, we saw one particular student's mother who could not sign up to an instructional app because she was not able to fill out a form. Furthermore, we also suggested the importance of emotions in the deployment of technology and literacy development in general, as conceptualized by emotional literacy studies.

The time is ripe for a reappraisal of educational goals, "departing from context and needs and resources from situated groups" (MENEZES DE SOUZA, 2019b, p. 14), as well as the assumptions underlying educational policies, including the ones about the nature and place of literacy in formal 
schooling. Such reappraisal can also lead to a critical scrutiny of our "metadiscursive regimes" (MENEZES DE SOUZA, 2019a), which in turn can help us identify and overhaul any eurocentric desires that inform our teaching practice. Therefore, literacy studies should consider the limitations of investigating language and literacy within an eurocentric - and hence colonialist, patriarchal, capitalist - framework based on such notions as "teaching", "assessment", "achievement", "progression", "discipline”, "grades" etc., as well as those binarisms unquestioningly deployed to conceptualize educational problems, such as "rational" $\mathrm{x}$ "irrational", "male" x "female", "mind" x "body", "literate" x "illiterate", among others (the first element in each binarism being superior to the second). Hence our suggestion that this reappraisal of educational goals be undertaken in a decolonial, critical literacy perspective, which interrogates concepts usually taken as universal or homogeneous, and can shed light on the process of coloniality reinforcing injustice and inequities in Brazil.

We would also like to suggest that this reappraisal incorporate Deleuze and Guattari's $(2000,2003)$ alternative logic of concurrence, which challenges the binarisms above and may provide a more lucid account of social, cultural and political issues. This logic characterizes nomadic thought, as mentioned above. Inspired by Deleuze and Guattari, we could conceive of digital literacy in nomadic, rhizomatic terms, for example: digital literacy $=\ldots$ emotions + critical + visual + spatial $+e$-literate + illiterate $+\ldots$ etc.

As applied linguists, English teachers, and literacy researchers who "continue to be vital forces in the reconstructions and transformations that the future requires" (JORGE, 2020, p. 248), our contribution to this reappraisal of educational goals and concepts could be in the form of literacy stories and experiences that can help imagine literacy, society and education in new ways, paving the way for the creation of a level playing field in which democracy can flourish.

\section{Authors' contributions}

Both authors wrote each section of this paper collaboratively. 


\section{References}

ASONYE, C. There's nothing new about the "new normal". Here's why. World Economic Forum, 2020. Available at: https:/ /www.weforum.org/agenda/2020/06/ theres-nothing-new-about-this-new-normal-heres-why/. Retrieved on: Jul. 29, 2020 .

BARCELOS, A. M. F. Letramento emocional no ensino de línguas. In: TOLDO, C.; STURM, L. (org.). Letramento: práticas de leitura e escrita. Campinas: Pontes Editores, 2015. p. 65-78.

BIESTA, G. Good Education in an Age of Measurement. Ethics, Politics, Democracy. London; New York: Routledge, 2010.

BIESTA, G. Beyond Learning. Democratic Education for a Human Future. London; New York: Routledge, 2015a.

BIESTA, G. What Is Education for? On Good Education, Teacher Judgement, and Educational Professionalism. European Journal of Education, [S.l.], v. 50, n.1, p. 75-87, 2015b. DOI: doi.org/10.1111/ ejed.12109.

BUZATO, M.E.K. Cultura digital e apropriação ascendente: apontamentos para uma educação 2.0. Educação em Revista, Belo Horizonte, v. 26, n.3, p. 283-304, 2010.

CHUN, C.W. The "Neoliberal Citizen": Resemiotizing Globalized Identities in EAP Materials. In: GRAY, J. (ed.). Critical Perspectives on Language Teaching Materials. Hampshire: Palgrave Publishers, 2013. p. 64-87.

COLL, C.; MAURI, T.; ONRUBIA, J. Os ambientes virtuais de aprendizagem baseados na análise de casos e na resolução de problemas. In: COLL, C.; MONEREO, C. Psicologia da educação virtual: aprender e ensinar com as tecnologias da informação e da comunicação. Transl. Naila Freitas. Porto Alegre: Artmed, 2010. p. 189-207.

DELEUZE, G.; GUATTARI, F. AntiOedipus. Capitalism and Schizophrenia. Transl. Robert Hurley, Mark Seem and Hele R. Lane. Minneapolis: University of Minnesota Press, 2000.

DELEUZE, G.; GUATTARI, F. A Thousand Plateaus. Capitalism and Schizophrenia. Translation and foreword by Brian Massumi. Minneapolis; London: University of Minnesota Press, 2003.

FAUPEL, A. Emotional Literacy: Assessment and Intervention. Ages 7 to 11. London: NFER; Nelson, 2003.

FREITAS, M.T. Letramento digital e formação de professores. Educação em Revista, Belo Horizonte, v. 26, n. 3, p. 335-352, 2010. 
HULL, G.; SCHULTZ, K. (ed.) School's Out. Bridging Out-of-School Literacies with Classroom Practice. New York: Teachers College Press, 2001.

JORDÃO, C.M. As lentes do discurso: letramento e criticidade no mundo digital. Trabalhos em Linguistica Aplicada, Campinas, v. 46, n. 1, p. 19-29, 2007. Available at: https://www.scielo.br/scielo.php?pid=S0103-18132007000100003\&script=sci_ abstract\&tlng=pt. Retrieved on: Jul. 29, 2020.

JORGE, M. Teacher Education for the Twenty-First Century (and a Post-Pandemic World). Revista Brasileira de Linguistica Aplicada, Belo Horizonte, v. 20, n. 2, p. 247250, 2020. DOI: https://doi.org/10.1590/1984-6398202016853

JUNQUEIRA, E. S.; BUZATO, M. E. K. New Literacies in the Context of Brazilian Historical Social-Economic Inequality. In: (ed.). New Literacies, New Agencies? A Brazilian Perspective on Mindsets, Digital Practices and Tools for Social Action in and Out of School. New York: Peter Lang, 2013. p. 1-21.

KUBOTA, R. The Multi/Plural Turn, Postcolonial Theory, and Neoliberal Multiculturalism: Complicities and Implications for Applied Linguistics. Applied Linguistics, Oxford, v. 37, n. 4, p. 1-22, 2014. DOI: https://doi.org/10.1093/applin/ amu045

LANKSHEAR, C.; KNOBEL, M. New Literacies: Everyday Practices and Classroom Learning. England: Open University Press, 2006.

LANKSHEAR, C.; KNOBEL, M. Digital Literacy and Participation in Online Social Networking Spaces. In: LANKSHEAR, C.; KNOBEL, M. (ed.). Digital literacies: concepts, policies and practices. New York: Peter Lang Publishing, 2008. p. 249-278.

MARTIN, A. Digital Literacy and the "Digital Society". In: LANKSHEAR, C.; KNOBEL, M. (ed.). Digital Literacies: Concepts, Policies and Practices. New York: Peter Lang Publishing, 2008. p. 151-176.

MATTHEWS, B. Engaging Education: Developing Emotional Literacy, Equity and Co-Education. Berkshire: Open University Press, 2006.

MENEZES DE SOUZA, L. M. T. Glocal Languages, Coloniality and Globalization from Below. In: GUILHERME, M.; MENEZES DE SOUZA, L.M.T. (ed.) Glocal Languages and Critical Intercultural Awareness. The South Answers Back. New York; London: Routledge, 2019a.

MENEZES DE SOUZA, L. M. T. "Eu só posso me responsabilizar pelas minhas leituras, não pelas teorias que eu cito": entrevista com Lynn Mario Trindade Menezes de Souza (USP). Revista X, Curitiba, v. 14, n. 5, p. 5-21, 2019b. 
RIBAS, F.C. Tecnologias digitais e ensino de língua inglesa na educação básica: o que revelam as pesquisas em Linguística Aplicada? In: LACERDA, M.M.; SOUZA, J. R. (org.). Tecnologias e o ensino de linguas. In press.

SANTOS, L. M. A.; EL KADRI, M. S.; GAMERO, R.; GIMENEZ, T. Teaching English as an Additional Language for Social Participation: Digital Technology in an Immersion Programme. Revista Brasileira de Linguistica Aplicada, Belo Horizonte, v. 18, n. 1, p. 29-55, 2018. DOI: http://dx.doi.org/10.1590/19846398201811456. Available at: https://www.scielo.br/scielo.php?script=sci_ arttext\&pid=S1984-63982018000100029. Retrieved on: Jul. 29, 2020.

SILVESTRE, V. P. V. Práticas problematizadoras e de(s)coloniais na formação de professores/ as de linguas: teorizações construídas em uma experiência com o Pibid. 2016. 239 f. Tese (Doutorado em Letras e Linguística) - Universidade Federal de Goiás, Goiânia, 2016.

SOUSA SANTOS, B. O fim do império cognitivo. A afirmação das epistemologias do Sul. Belo Horizonte: Autêntica Editora, 2019.

SOUSA SANTOS, B. A cruel pedagogia do vírus. Coimbra: Edições Almedina, 2020. E-book. Available at: https://www.almedina.net/a-cruel-pedagogia-do-vrus-1586961170.html. Retrieved on: Jul. 29, 2020.

STANISCUASKI, F. et al. Impact of Covid-19 on Academic Mothers. Science, [S.l.], v. 368, n. 6492, p. 724, 2020. Available at: https:/ / science.sciencemag.org/ content/368/6492/724.1. Retrieved on: Jul. 29, 2020.

WARSCHAUER, M. Researching Technology in TESOL: Determinist, Instrumental, and Critical Approaches. TESOL Quarterly, [S.l.], v. 32, n.4, p. 757761, 1998.

WEARE, K. Developing the Emotionally Literate School. London: Paul Chapman Publishing, 2004.

WELLINGS, J.; LEVINE, M. H. The Digital Promise: Transforming Learning with Innovative Uses of Technology. A White Paper on Literacy and Learning in a New Media Age. New York: Joan Ganz Cooney Center at Sesame Workshop, p. 1-17, 2009. Available at: https://joanganzcooneycenter.org/publication/white-paperthe-digital-promise-transforming-learning-with-innovative-uses-of-technology/. Retrieved on: Jul. 29, 2020.

Data de submissão: 19/08/2020. Data de aprovação: 09/03/2021. 